Article

\title{
The White Mountain Recreational Enterprise: Bio-Political Foundations for White Mountain Apache Natural Resource Control, 1945-1960
}

\author{
David C. Tomblin \\ Science, Technology and Society Program, University of Maryland, 1125 Cumberland Hall, College Park, \\ MD 20742, USA; dtomblin@umd.edu; Tel.: +1-301-405-0527 \\ Academic Editors: Karen L Thornber and Tom Havens \\ Received: 30 November 2015; Accepted: 25 January 2016; Published: 15 July 2016
}

\begin{abstract}
Among American Indian nations, the White Mountain Apache Tribe has been at the forefront of a struggle to control natural resource management within reservation boundaries. In 1952, they developed the first comprehensive tribal natural resource management program, the White Mountain Recreational Enterprise (WMRE), which became a cornerstone for fighting legal battles over the tribe's right to manage cultural and natural resources on the reservation for the benefit of the tribal community rather than outside interests. This article examines how White Mountain Apaches used the WMRE, while embracing both Euro-American and Apache traditions, as an institutional foundation for resistance and exchange with Euro-American society so as to reassert control over tribal eco-cultural resources in east-central Arizona.
\end{abstract}

Keywords: American Indian; White Mountain Apache; natural resource management; eco-tourism; glocalization

\section{Introduction}

This is a story about the appropriation of science, technology, and capitalism as tools of liberation, a moment in White Mountain Apache history where the tide began to turn in their resistance to the cultural hegemony of the United States government. This story is as an opportunity to illustrate a particular way that a local, place-based non-Western community responded to a wave of globalization after World War II. As Arturo Escobar points out, "Subaltern strategies of localization still need to be seen in terms of place; places are surely connected and constructed yet those constructions entail boundaries, grounds, selective connection, interaction, and positioning, and in some cases a renewal of history-making skills" ([1], p. 169).

Globalization has always been a process of entanglement among cultures: in essence a "glocalization process" [2]. For American Indians, this began when the first European explorers set foot in the Western Hemisphere and intensified with colonization. Both Richard White's The Middle Ground and James Merrell's The Indians New World provide excellent examples of Native American social and political flexibility in the seventeenth to early twentieth centuries to reimagine their societies in the wake of ecological change and cultural disruption. They illustrate that the cultural appropriation and adaptation of Western technology proved key to the long-term survival and reinvention of American Indian culture [3,4]. This process of entanglement, what I call resistance and exchange, has continued into the twenty-first century and remains an important process of identity formation for American Indian groups [5-7].

It is from the subaltern, as a subject of the settler colonial power structure of the United States, that the White Mountain Apache Tribe and all other American Indian groups have reinvented their relationships with the land, their communities, and outside influences. White Mountain Apaches have 
shown that resistance to global forces is not futile, but requires a reimagining of tribal identity and interacting with non-Apache cultures. This resistance involves the retention and reinvention of local cultural attributes, knowledge, and technology but also involves appropriating and reformulating cultural attributes, knowledge, and technology of the hegemonic culture.

The White Mountain Apache Tribe exemplifies how globalization doesn't necessarily lead to cultural homogeneity, but a hybridization process. Rather than a single capitalist system, knowledge production system, and technological ethos, globalization leads to multiple capitalisms, multiple knowledge production systems, and multiple technological ethoses resulting from resistance and exchange that occurs among the dominant cultures and historically subjugated cultures [8-10]. The local and global have permeable, fluid boundaries where exchange occurs, albeit in an unbalanced way. Instead of wiping out local cultures, this process creates new cultures, retaining some traditions and spawning new cultural inventions that are rooted in maintaining close ties and identity with place. As Nelson Lupe, Sr., a White Mountain Apache leader in the 1950s and co-founder of the White Mountain Recreational Enterprise (WMRE) asserted, "We're not dying off... We're growing ([11], p. 37)." This was a call for cultural survival in the early 1950s that entailed the realization that Apaches must appropriate Euro-American science and technologies in order to maintain some level of cultural identity and ties to their homeland. For White Mountain Apaches, this place is the White Mountains of east-central Arizona on the Fort Apache Indian Reservation.

Maintaining sovereignty within the limits of the United States government's federal fiduciary responsibilities necessitated that American Indian groups establish modern governments, with bureaucratic and legal machinery to cope with county, state, and federal influences. The struggle of modern Native American state formation throughout American Indian history can only be understood as a reaction to settler colonial forces pushing for the liquidation of American Indian traditional governments or any government at all, including those established, reestablished, or reorganized under the Indian Reorganization Act of 1934 [12]. All American Indian groups continue to face this struggle. However, the pathway of resistance and exchange for maintaining a sovereign status, enforcing the trust relationship and the fiduciary responsibility of the United States government and its bureaucratic resource for American Indians, the Bureau of Indian Affairs (BIA), is context-dependent [13-16]. Each American Indian group has its own story and different levels of success. To illustrate how White Mountain Apaches opposed socio-political forces that attempted to limit their cultural and political autonomy in the middle of the twentieth century, this article tells the story of the formation of the White Mountain Recreational Enterprise in the 1950s, which marked a turning point toward regaining control over Apache destiny on the Fort Apache Indian Reservation. I argue that the WMRE, an Apache/Euro-American hybrid construct, became an organizational foundation for resistance to and exchange with Euro-American society that impelled the Apache people's quest to maintain tribal sovereignty and control eco-cultural resources on the reservation.

\section{The White Mountain Apache Tribe and the Political Origins of the WMRE}

The Ndee (the People) consist of several subgroups (White Mountain, Cibecue, San Carlos, Northern Tonto, and Southern Tonto) that belong to the Western Apache group [17,18]. Both Cibecue and White Mountain Apaches live on the Fort Apache Indian Reservation. ${ }^{1}$ To create a sovereign identity, they have collectively chosen to call themselves the White Mountain Apache Tribe, although locally tribal members still distinguish between the two subgroups. Unlike many other Native American groups, the federal government created Fort Apache from a small fragment of their former homeland, the White Mountains of east-central Arizona.

1 For stylistic reasons, I intermittently shorten White Mountain Apaches to Apaches. In addition, I shorten Fort Apache Indian Reservation to Fort Apache, not to be confused with the actual historic military Fort Apache that resides within the reservation boundary. 
In order to survive as a culture, the tribe depends greatly on an extensive renewable natural resource base. The reservation population has more than quadrupled since the 1930s from approximately 3000 to 13,000 members as of 2010 [19]. This population growth, along with the Apache people's desire to remain a sovereign nation, furthers their dependence on the reservation ecosystem's goods and services. Currently timber, cattle, hunting, fishing, ecotourism, cultural heritage tourism, a ski resort, a casino, agriculture, two manufacturing companies (Apache Aerospace Company and Apache Materials), and a number of retail stores support their economy [20]. The WMRE to a certain extent made much of the current WMAT economy possible. Its establishment allowed the WMAT to experiment with and adapt non-Apache knowledge systems, technology, and business practices to their community needs. It allowed many Apaches to experimently determine effective ways of a interacting with Euro-American cultures so as to maintain Apache sovereignty and cultural identity: in essence, protect themselves against legislative efforts to dissolve fiduciary obligations and tribal sovereignty. While many Apaches at the time thought this was a risky proposition-to tangle with Euro-Americans was to be dominated by them and become like them-others thought the risk was necessary.

The White Mountain Recreational Enterprise's (WMRE) establishment in 1952 marked it as the first American Indian recreational business on an Indian reservation in the United States [21]. ${ }^{2}$ For the first time, White Mountain Apaches formed an independent organizational boundary, outside the tribal government, between themselves and Euro-American society. On the surface, the WMRE embraced the ideals of Euro-American land management and business techniques, developing reservation resources to generate revenue and supply jobs for tribal members. Upon a closer look, however, the WMRE embodied the tribe's quest to restore control over reservation resources. This enterprise made it possible for Apaches to escalate the appropriation of Euro-American science and technology for the benefit of the tribal community rather than outside interests, becoming an economic cornerstone from which they could rebuild their society. Furthermore, the WMRE became a platform from which Apaches could begin mediating and participating in knowledge production on the reservation, creating training programs that expanded the pool of Apache expertise. Some of these programs led to long-term career opportunities, contributing to a modest measure of economic stability for some tribal members.

Thus the WMRE became an institutional foundation for resistance to and exchange with Euro-American society and the intensification of globalization in the post-World War II climate. Although globalization is often seen as a homogenizing force projected outward from developed nations toward developing nations, in the United States, globalization has also been turned inward toward North America's original inhabitants in vacillations between nation building projects and assimilation policies (e.g., allotment of tribal lands). U.S. policy toward American Indians has been far from stable, but has been consistently paternalistic, coercing American Indians to adopt Euro-American lifestyles that fostered a culture of dependence until the 1970s [22]. Coming off a short-lived nation building effort known as the Indian New Deal that ended in the wake of World War II, the whims of the United States government swung back toward an assimilation policy that sought to extinguish its fiduciary responsibility and American Indian treaty rights, and thus any notion of tribal sovereignty. American Indians know this last grand assimilation effort, which occurred roughly from 1945 until the early 1960s, as the Termination Era.

Although the federal government had been practicing termination policy since 1945, it was not until 1953 that the U.S. Congress enacted Public Law 280, its legislative foundation. The Congressional architects of this legislation designed it to further dissolve federal responsibility for American Indians, authorized funding cuts for many federal American Indian services, and authorized states to assume jurisdictional control over criminal and civil law on reservations [23-25]. Essentially, the goal of the policy was to assimilate all American Indians into Euro-American society, "to make the Indians

2 The tribal council did not officially establish the WMRE until 1954. 
within the territorial limits of the United States subject to the same laws and entitled to the same privileges and responsibilities as are applicable to other citizens of the United States, to end their status as wards of the United States, and to grant them all of the rights and prerogatives pertaining to American citizenship" [26]. With its ideological roots in the individualist ethos of liberal economics, the homogenizing intention of the policy was to "liberate" Indians from the shackles of federal responsibility [27].

To administer this policy, tribes considered economically "self-sufficient" would have their lands taken out of federal trust, making them taxable, and would have federal support withdrawn, including basic services such as health care and education. Many tribes feared the consequences of termination because not only would it represent an abrogation of treaty rights and a denial of the federal trust responsibility, but withdrawal of services could also devastate the cultural integrity and tribal sovereignty of even the most economically advanced nations $[5,13]$.

The WMRE emerged during this era. At the time the main forms of White Mountain Apache subsistence came from cattle and local farms, with Euro-American timber operations providing a source of wage labor for some. To get a sense of the White Mountain Apache Tribe's level of "self-sufficiency", Congress urged the Bureau of Indian Affairs (BIA) Central Office in Washington to conduct several studies to assess its withdrawal status. The reservation superintendent at the time, John Crow, suggested that the Apaches remained far from ready. Their lack of business, legal, and political experience on top of a persisting "low level of educational achievement" would leave the White Mountain Apache Tribe vulnerable to economic failure, pushing it further into poverty. He warned that because of the tribe's relative geographical and cultural isolation from the non-Indian world, "at best, assimilation will be a slow process" [28]. Ironically, while the purpose of termination policy was to push assimilation, in practice, it politically reinvigorated tribal politics in the United States. Many American Indian groups, including the White Mountain Apache, began economic and natural resource development projects, such as the WMRE, to reassert political autonomy and sovereignty ([29], p. 173).

Two figures in Apache history are prominent in the establishment of the WMRE: Nelson Lupe, Sr., a long-time tribal leader and two-time tribal chairman, and Silas Davis, a Euro-American and career Bureau of Indian Affairs forester who labored on the Fort Apache Reservation for the better part of two decades. Together, they worked tirelessly to create an Apache/Euro-American hybrid organization. In many ways, Lupe was a prototype of the Apache hybrid boundary worker that became more common later, well-versed in both Euro-American culture and his own culture, harboring extensive Apache historical, ceremonial, and religious knowledge [30]. Because of his ability to move back and forth between cultures with relative ease, he understood how to build an enterprise that would benefit the Apache community rather than outside interests. Beyond the economic benefits of tourism, he believed revenue from these endeavors could help support "a repository for articles of Apache culture and records which are fast disappearing" [31]. To convince the tribal council and Apaches in general of the merits of the WMRE, Lupe argued that by allowing non-Indians onto the reservation, the tribe could begin to compensate itself economically for past losses, asserting, "As long as we develop our land...we'll have something...to be proud of and something that we can claim as our own and something that we have done ourselves in developing the resources ([11], p. 38)." Through selling fishing and hunting permits, building hotels and gas stations, and creating lake resorts, the Apaches could assume control of their own economic future. No longer would they have to rely exclusively on the whims of the BIA and outside business interests. Lupe's economic argument implied that for Apaches to maintain their sovereignty and restore their cultural identity, they had to develop an independent economic base. Only from this standpoint would the tribal government acquire any political sway in its own affairs.

Silas Davis, well-liked among Apaches, brought his long history of working productively with Apaches, his natural resource management expertise, and his political leverage within the BIA to bear [32,33]. Two decades of forestry work on Fort Apache and training Apache fire fighters allowed 
Davis to build an intimate relationship with the White Mountain landscape and a solid reputation among Apaches. Truly enjoying his work with Apaches and having developed deep ties to the Apachean landscape, Davis relished the idea of devoting his services to the WMRE [34]. As a show of appreciation for his "long record of service" to the Apache people, the tribal council "granted [him] a lifetime free privilege of hunting and fishing on the Fort Apache Indian Reservation" [35].

Lupe and Davis's friendship marked a new level of exchange that went beyond a paternalistic, top-down model of knowledge production. Their relationship was built on a more even playing field: Lupe provided the political will and ability to convince a reticent tribal council of the merits of a recreational enterprise, and Davis shared his intimate knowledge of the Fort Apache landscape and conservation techniques. Lupe claimed in an article about the WMRE in Sports Illustrated that he and Davis would have long conversations about developing a recreational enterprise. Lupe drew off his weekend recreational experiences while working at a copper smelting plant in Morenci, Arizona during World War II to imagine how Fort Apache could become a recreational hotspot: "It was Sy [sic] Davis who kind of pictured the whole thing to me. We'd talk about the streams. We'd drive out, and he'd say, 'Wouldn't it be wonderful, Nelson, to have a campground in here? We could sell fishing licenses and stock the stream with fish, so fishermen can come back here and give us some money in the summertime.' And right then and there, my mind went back to Morenci" ([11], p. 38).

Ultimately the WMRE provided the White Mountain Apache Tribe with political and economic leverage that it had never experienced before. As revenues increased, the tribal council reinvested in the recreational infrastructure of the reservation and, more significant, the ecological restoration of the Apache homeland. Its primary mission remained the protection, restoration, and conservation of "wildlife, recreational, and natural resources of the White Mountain Apache Indian Reservation for the members of the Tribe and the general public". And perhaps most important, in the spirit of resistance and exchange, the enterprise served as a "liaison...with State and Federal Agencies concerned with... wildlife and recreational resources" [36].

Until 1957, the enterprise derived most of its revenue from fishing permits and a few hunting permits. The WMRE's revenue source greatly increased with the construction of the Indian Pine Service Station and Motel Cabins (later known as Hon-Dah), the first tribally owned retail complex. Strategically positioned at the northwestern reservation entrance, these facilities functioned to capture the growing number of tourists entering Fort Apache. All of this increased interactions with Euro-American worlds but from a relatively increased position of power, a position where Apaches could effectively resist exploitation and also benefit from knowledge and technique exchanges with Euro-American institutions. What follows explores both sides of this process, a resource battle over water rights on the reservation and partnerships that formed as a result of the WMRE.

\section{Hawley Lake as a Site of Resistance}

Inevitably, with the growth of the WMRE, came resource battles with Euro-Americans. The construction of Smith Park Reservoir (later renamed Hawley Lake) to increase the recreational capacity of the reservation represented the White Mountain Apache government's first significant sovereign extension of the WMRE to resist non-Indian influence over reservation resources [37]. ${ }^{3}$ The emerging political and economic leverage of the WMRE afforded the tribal government the capacity to fight institutions that had historically exploited tribal resources with little consequence. No longer were Apaches solely reliant on the BIA, whose decisions did not always work for the best interests of the Apaches.

The battle over Smith Park Reservoir began in 1954, as the WMRE laid plans to build the dam. The Salt River Valley Water Users' Association (SRVWUA) objected to the construction of the dam

3 Smith Park Reservoir was later renamed Hawley Lake in honor of Albert Hawley, the reservation superintendent of Gros Ventre heritage who helped the tribe overcome legal hurdles related to the construction of the reservoir. 
on the grounds that the WMRE was impounding water that the SRVWUA had claimed prior rights to for irrigating farms downstream of the reservation. The conflict came to a head in 1957 among sensational reports about the construction of the lake taking place under the protection of armed Apache guards. These stories inflamed racist images of Apaches as aggressive warriors, reviving visions among Euro-Americans of the nineteenth century Apache wars. These claims, however, were probably blown out of proportion, as even the Apache County sheriff, who made several visits to the reservation during the conflict, admitted, "There were no hard words ...They were just doing their job" [38]. Contrary to rampant rumors, "there has been absolutely no violence in connection with any actions of the tribe relating to Smith Park Dam, nor has any physical force been brought to bear upon any person to prevent his entering the construction area" [38]. However, some Apache leaders used this same opportunity to create support for the project among the Apache people. Lester Oliver, a tribal council member who eventually became a tribal chairman, told a different story: the sheriff pulled a gun on the guards, only retreating after he realized he was in the sights of an Apache rifleman perched on a nearby cliff. He also claimed to receive an anonymous phone call threatening that if Apaches remained on the "war path", the state would "send in the National Guard" [39]. Amidst conflicting reports, tensions ran high between Apaches and the SRVWUA.

Initially in 1954, when the SRVWUA learned of the Apache plan to create the reservoir, it didn't outright object to the project. The SRVWUA believed, however, that according to the Kent Decree, an Arizona court case in 1910 that supposedly adjudicated water rights in Arizona, it had rights to all water in the Salt River watershed. Realizing, however, that the decree never considered the White Mountain Apache Tribe, whose reservation encompassed the headwaters of the Salt River, the SRVWUA offered that it would allow the construction of the dam under the condition that the tribal council signed an agreement recognizing the SRVWUAs' claim to all the water in the Salt River Basin. The BIA's Phoenix Area Director F. M. Haverland, describing the request as "unconscionable", counseled against signing the agreement [38]. After all, the federally established Winters Doctrine of 1908 trumped the Kent Decree, giving Native Americans prior use rights to water on their reservations.

In 1955, the SRVWUA threatened court action if the WMRE proceeded with the project. In response, Si Davis, Lester Oliver, and Nelson Lupe joined A. B. Melzner and Geraint Humphreys, field solicitors for the BIA, to determine whether the SRVWUA had a solid case. They determined that first, the construction of the dam would only minimally impact the flow of the Salt River; second, the White Mountain Apache Tribe held water rights equal to or above those of the SRVWUA because of the Winters Doctrine; and third, the contested watershed resided entirely within the bounds of the reservation, thus giving Apaches clear jurisdiction over the construction site. Based on these conclusions, the BIA encouraged the tribal government to proceed with the project [40].

Believing the law was on their side, Apaches commenced work in August 1956, only to stop five weeks later. The SRVWUA obtained a court injunction to halt construction "on the justification that the dam would result in undue water loss on account of evaporation" [41]. On 7 September, 1956, the deputy sheriff of Apache County served the construction company hired by the WMRE with a temporary restraining order. With their water rights thrown into jeopardy, tribal officials again sought the advice of the BIA; unfortunately, this time, the BIA wavered. Suddenly the tribal council and the WMRE found themselves fighting a battle on two fronts, BIA bureaucracy and the SRVWUA.

In response, Clinton Kessay, the current tribal chairman, outlined in a letter to BIA Commissioner Glenn Emmons what was at stake:

Our water and the right to use our water to develop our resources is vitally important to us as a tribe, and we are therefore very anxious to know just what the Bureau of Indian Affairs position is and what action we can expect from the Solicitor's office regarding the present pending lawsuits and what we can expect if in the future the White Mountain Apache Tribe's water development program is harassed by outside agents [42].

Kessay's letter conveyed inherent distrust in the BIA's ability to protect Apache resources. The BIA had initially backed the project but subsequently took a weak position on the matter [43]. The lack 
of action perhaps wasn't surprising given that termination policy was in full swing by this point. An administration seeking the eventual assimilation of all tribes into mainstream society probably wasn't in a hurry to defend White Mountain Apache sovereignty. However, this time, the law was on the Apaches' side. They joined a surging wave of tribal lawyers and Native American political movements that were beginning to challenge termination policy and hold the federal government under a legal microscope [44].

With the BIA dragging its feet, Barry DeRose, the White Mountain Apache tribal attorney, and the tribal council pressed the issue. On 5 February 1957, DeRose, along with a tribal delegation, traveled to Washington to discuss a loophole in the case with the BIA and other government officials. The tribe had found a loophole in the lawsuit: it only named the construction company the tribal government had hired to work on the project, failing to list the White Mountain Apache Tribe or the BIA. As long as the WMRE constructed the reservoir, the tribal government wouldn't technically violate the court injunction [45]. Taking matters into their own hands, in April 1957 the tribal council passed a resolution authorizing the acquisition of rented construction equipment and the completion of the dam [46].

Despite the tension with the SRVWUA, the WMRE moved forward with the project under armed guard. The SRVWUA caught wind of the construction soon after it recommenced. On 4 June 1957, they attempted to serve legal documents to the tribal government. To avoid being served, Chairman Kessay, Vice Chairman Lupe, and other tribal leaders fled to New Mexico [47]. In addition, under orders not to admit anyone on to the construction site "unless authorized by the tribal council", Apache armed guards rebuffed the Apache County sheriff's attempt to serve a new restraining order. In the meantime, WMRE workers completed the dam. State officials returned the following morning with armed "body attachments" to find the worksite deserted and water already filling the reservoir [38]. Two years later the reservoir was full and open for business.

Finally, despite a jungle of legal and bureaucratic hassles, the WMRE had managed to create Hawley Lake. The lake eventually served two major purposes: diversifying fisheries management options and increasing the profitability of the WMRE [48]. The WMRE, with tribal council approval, constructed three more reservoirs (Hurricane, Pacheta, and Drift Fence) in 1959 and another in 1960 (Earl Park), all while the Hawley Lake dispute persisted in court. With defiant plans to construct more reservoirs, Apaches had built a total of seven reservoirs on Fort Apache by 1960, while, to no avail, the SRVWUA continued efforts to have the Smith Park Dam removed [49].

\section{Creating Mediated Pathways of Exchange}

With resistance came increased exchange, and the glocalization process intensified. Exchange emerged in five different ways in the 1950s: through media interventions, guided tourism visits, training partnerships with state and federal agencies, ecological restoration work, and demonstrations of best management practices with other tribal governments. Exchange in many ways was more complicated than resistance. In their interactions with outsiders, Apaches had to balance expertise of both Apache knowledge and Euro-American land management and business techniques in order to negotiate the epistemological boundaries between Apache and Euro-American cultures. A prominent presence of Apaches required outsiders to address local cultural and environmental concerns. Although Apaches stood to learn useful natural resource management and business techniques from outsiders, their ability to move fluidly among different knowledge systems allowed them to determine whether the interests of outsiders (e.g., BIA officials, state and federal natural resource management agencies, private business interests, tourists, etc.) were in line with Apache interests. Building these mediation skills through WMRE work, Apaches absorbed new knowledge while simultaneously protecting Apache assets. Eventually, tribal government officials and WMRE employees began to embody the process of resistance and exchange, cautiously erecting selective boundaries that delineated between knowledge that would benefit Apaches and knowledge that lacked application to Apache circumstances. What follows are a few examples of White Mountain Apaches building this multi-knowledge system in the 1950s. 
If the recreational enterprise was going to be successful and attract Euro-Americans to the reservation, White Mountain Apache tribal officials realized they needed to mediate negative myths about Apache culture that were common in Euro-American culture. This knowledge exchange occurred at a very high level through the media. At the time, there were still persistent myths, which lingered from the wars of the 1800s, among the non-Indian public about the aggressive and unfriendly nature of Apache people. Much of this image was refueled in the press during the Hawley Lake controversy [50]. Soon after establishing the WMRE, the tribal government began work on public relations, promoting the enterprise in newspapers and magazines such as The Arizona Republic, The New York Times, Arizona Highways, and American Legion Magazine [51-53]. These articles often described the Fort Apache Indian Reservation as a primeval wilderness. Arizona Highways referred to the White Mountains as "the last remaining perfect wilderness area in the state" ([52], p. 13). In American Legion Magazine an article titled, "Apacheland Welcomes White Man", depicted the Hawley Lake area as "virgin forests of spruce, fir, and aspen" where one would have to pause "often to rhapsodize over the glorious scenery and gape at animals we'd never seen at such close range" [53]. Here, WMRE officials were capitalizing on Euro-American desires for a wilderness experience, which a growing American middle-class with disposable incomes began seeking in the 1950s [54,55].

Another strategy for exchange involved tribal officials spending time with journalists visiting the reservation. Following one such visit, Richard Dunlop of the Saturday Evening Post wrote an article that played off of old Apache stereotypes. As the subtitle of the article indicates-"A family of palefaces from the Midwest spends its vacations on an Arizona reservation and learns Indian outdoor lore from Apaches whose ancestors once shot it out with U.S. Troopers"[56] — it did the double duty of assuaging public fears of Apaches, while advertising the recreational benefits of the reservation by turning such stereotypes on their head. Tribal leaders used these stereotypes to redraw Apache/Euro-American boundaries to their advantage. Clearly welcoming the characterization of the Wild West, Nelson Lupe traveled along with the Dunlop family and showed them "cliffs from which Apache snipers once shot down blue-coated troopers". At the same time, Lupe wasn't shy about the limits of the exchange: "Apaches have always lived around here ...We always will. We fought hard to keep this country. We know that whites are still trying to take it away from us. If we fail to develop our reservation, sooner or later outsiders will do it" [56]. Outsiders could visit the reservation, but they would have to leave, asserting a message of Apache independence and perseverance.

Tribal Chairman Lester Oliver worked to dispel the common myth that all Native Americans were on a "federal dole" at taxpayers' expense. Oliver was good at cleverly co-opting Euro-American rhetoric for Apache benefit. For example, he turned this comment found in a local Arizona conservation association report into positive press for the WMRE:

The Whiteriver Apache Indian Reservation lies across a fence from the Tonto Soil Conservation District. Their conservation efforts...are handled in a semi-democratic, semi-fascistic manner. ...In conservation, restoration, water yield and water salvage, the Reservation is years ahead of us. Why should lands under the trusteeship of the Department of Interior come up with answers to present day land management problems so far ahead of lands administered under the U.S.D.A.??? [sic] At the start of their conservation program, their lands were in worse condition than the Forest lands are today. The White Mountain Apache Reservation is the most encouraging spot on the Salt River watershed [57].

Oliver referred to this comment in a letter to BIA officials: "I sincerely hope that our Tribe deserves these remarks, except perhaps for the one 'semi-democratic, semi-fascistic', whatever that means" [57]. Again, doing double duty, Oliver policed the political and environmental boundaries of the Apache homeland with subtle wit, taking credit for the natural resource management successes of the tribe while correcting political misconceptions about the tribal government.

Tribal officials also reinforced and created new relationships of exchange with federal and state natural resource management agencies through cooperative agreements with the United States Fish and Wildlife Service (FWS) and the Arizona Game and Fish Commission (AGFC) concerning the 
operation of the Williams Creek Fish Hatchery, which was built on Fort Apache in 1939 [58]. Under the new agreement, Apaches recommitted the land and water for fish-cultural operations and took on more responsibility for distributing fish from the hatchery to waters on the reservation [59].

Some Apaches received technical training through this relationship, learning fishery management techniques and creel census methods for measuring fisher and hunter resource consumption. For example, they learned how to sample fish populations to determine the extent streams needed restocking. Fish populations were estimated by circulating electricity through streams with a 110 volt AC generator. An Apache trainee group consisted of one person handling the electrodes, another handling the cord, and three others extracting temporarily stunned fish with dipping nets. They typically sampled ten 500 foot stretches of streams, including areas of heavy and light activity, to determine how fishing intensity affected fish distribution. After measuring and tagging each fish with a unique number, they returned them to the stream [60].

The WMRE also collaborated with the AGFC in a pronghorn antelope transplant project in 1959. Antelope had all but disappeared from the reservation in the late 1930s, with only occasional sightings of a few individuals in any year thereafter. Many Apaches worked with the AGFC to trap and transport pronghorn antelope from viable populations around Flagstaff, Arizona and reintroduce them to Bonita Prairie on the reservation [61]. Within four years, the transplanted population increased to a size sufficient to allow a limited hunt [62].

This training was particularly important because the tribal council had assumed the responsibility for determining bag and take limits on the reservation. In this new arrangement, the tribal government depended on accurate fish and game population estimates from the WMRE. In the tribal council's determinations, tribal members received first consideration. Any surplus game, without unduly depleting populations, became available to non-Indian recreational hunters and fishers. The council also determined which species non-Indians could hunt; deer, turkey, and the Apache trout, for the most part, remained off limits to non-Indians until the 1970s [36].

On top of building relationships with federal and state agencies, the early success of the WMRE found Apaches in a leadership position among Native American groups adopting recreational programs. Thanks to "the effective program" on Fort Apache, the FWS experienced a general increase in demand for its services to initiate recreational enterprises on southwestern reservations in the late 1950s [63]. The San Carlos Apache, Navajo, Papago, Salt River, Gila River, and Colorado River reservations all had programs by the early 1960s. In 1962, the Nez Perce Tribe of Idaho requested a visit from Chairman Oliver and Superintendent Hawley to advise it on starting a recreational program. In subsequent years, knowledge exchange between the White Mountain Apache Tribe and other native nations increased, as representatives from another forty tribes visited Fort Apache to study the inner workings of the WMRE [52,64].

\section{Foundation for Cultural Autonomy in the Twenty-First Century}

The 1950s signified a period when the White Mountain Apache Tribe, through the development of tribal enterprises, began to exert more power. As the 1950s drew to a close, the WMRE had become a profitable business supplying a growing number of jobs to the Apache people, not only as natural resource managers but also as hotel managers and clerks, store and gas station attendants, maintenance workers, bureaucrats, legal experts, and craftspeople. In many ways, while having major implications for the institutional capacity of the White Mountain Apache Tribe, some of the more important interactions occurred among individuals of different cultures. Such interpersonal interactions were by no means a story of complete domination of one culture by another. For example, Nelson Lupe and Si Davis were individuals helping each other out, respecting each other's culture. This relationship is symbolic of the many entanglements Apaches embraced in the future in order to reassert the tribe's cultural identity and political autonomy. The point here is not to dwell on the obvious negative past experiences of the White Mountain Apache Tribe with Euro-American paternalism and resource exploitation. Apaches had their fair share of well-documented bad experiences with archaeologists, 
anthropologists, Christian religious leaders, natural resource managers, and businessmen, but they also had positive entanglements with Euro-American cultures. For instance, Si Davis, like Apaches, had strong ties to the Apache homeland, making him a strong advocate for Apache causes.

Leaders such as Nelson Lupe and Si Davis exemplified what Dean Nieusma calls middle-out social change [65]. This process leverages expertise from both the dominant and local cultures without privileging one position of expertise over the other. Lupe and Davis, among many future Apache and Euro-American leaders on the reservation, avoided both a top-down management approach and a purely "traditionalist" grassroots resistance to the dominant culture. Together, using knowledges from Euro-American and Apache cultures, they helped create change from a middle ground. Their understanding of how things should work was more local and built on some level of exchange among cultures, with effective advocacy balancing the tension between service to the "elite" (a top-down bureaucratic organization like the BIA) and the isolationist tendencies of some Apaches [66]. By the 1980s and 1990s, evolving bureaucratic organizational and legal structures within the White Mountain Apache Tribe, the Arizona state government, and the federal government made middle-out social change more feasible and prominent.

Cultural entanglement played out not only with the WMRE but also with other tribal enterprises in the 1950s. The tribal government also established a sawmill and lumber company (Apache Mercantile Company), which while largely unsuccessful during the 1950s, still symbolized an act of independence that led to a more successful operation known as the Fort Apache Timber Company in the 1960s [67]. Ultimately, lessons learned from tribal businesses translated into knowledge and political capacity to deal effectively with many lingering issues, such as the removal of Euro-American ranchers from the reservation. Through this ordeal, tribal ranchers and land managers learned about range management, as they realized the importance of establishing regulations and grazing associations for running a more effective cattle business [68].

Through these glocalized political and economic successes, the tribal government began molding the WMRE, the cattle industry, and the tribal sawmill as tools for expanding influence over reservation resources, assuring economic security and establishing political autonomy. Restoration of the homeland and building technical capacity remained important challenges of this political exercise. The WMRE, along with the cattle industry, had created a solid foundation for growth. The road to autonomy still presented many obstacles, but the path forward was more obvious than a decade earlier. The tribal council, having learned through its experiences with tribal enterprise development, continued to look for ways to wrest control of eco-cultural resources away from the BIA, other federal agencies, and the Arizona state government. By the 1970s, the White Mountain Apache Tribe had a nationally recognized endangered species restoration program, and by the 1990s it pioneered a form of agreement with the federal government that allowed the tribe to manage endangered species on the reservation without extensive federal oversight. Most important, the agreement reaffirmed Apache sovereignty: “Tribal sovereignty [White Mountain Apache Tribe] and Service [FWS] legal mandates, as applied by the Service, have appeared to conflict in the past, but both the Tribe and the Service believe that a working relationship that reconciles the two within a bilateral government-to-government framework will reduce the potential for future conflicts ([69], pp. 733-44)."

The thrust of the agreement emphasized that the FWS recognized "the Tribe's aboriginal rights, sovereign authority, and institutional capacity to self-manage" reservation lands and eco-cultural resources. The agreement also outlined Apache institutional responsibilities to continue updating their wildlife management program and develop management plans under FWS consultation that "will direct the assessment, management, and restoration of ecosystems in accordance with tribal values" [69]. This agreement would also become a model for how many other American Indian nations would handle infringements of tribal sovereignty by the federal government [70]. Endeavors such as this, among many more, led to explicit integration of natural resource management with cultural restoration projects [71,72]. 
Of course, the road toward political autonomy and eco-cultural revitalization hasn't been easy and the sustainability of this effort remains a challenge. The Rodeo-Chediski fire of 2002 wreaked havoc on the reservation's Ponderosa pine ecosystem, burning 276,000 acres of Apache timber. This led to the temporary shutdown of the tribe's timber operations and threatened a number of culturally important places and resources, setting back the significant economic gains and eco-cultural restoration efforts of the 1990s [73,74]. Even though tribal timber operations eventually resumed, more than a decade later, White Mountain Apaches are still feeling the economic and ecological impacts of the Rodeo-Chediski fire. This event illustrates the fragility of any political gains White Mountain Apaches have made in the past 60 years. While the WMRE and subsequent progress that stemmed from it marked significant improvements for Apaches, it is important to realize that as a nation, they still remain economically and ecologically vulnerable. Too many large-scale catastrophic events can easily lead back to times where Apaches are more dependent on federal resources, which in turn would threaten gains in political autonomy.

\section{Conclusions}

Ultimately, however, catastrophic events such as the Rodeo-Chediski fire emphasize why resistance to certain Euro-American ideals remain important, yet exchange with the dominant society became a necessity. In order to survive as a culture, the White Mountain Apache Tribe had to develop a diverse economic and natural resource base. It is this diverse base that allows Apaches to weather high impact events like the Rodeo-Chediski fire. It is important not to think of the WMRE and subsequent Apache endeavors, which are cultural hybridizations of Apache and Euro-American natural resource management and business practices, as a compromise; rather it is a strategy for maintaining a cultural identity. Far from a homogenization process, glocalization is about global forces being reshaped by local imperatives. Through entanglement and hybridization, the process borrows from multiple cultures to create new cultures. While these sorts of processes have been occurring since cultures emerged within the human species, what is relatively new in the United States is that historical power imbalances have slowly begun to be corrected. The power imbalances are still there, but many American Indian groups are in a better position to protect themselves from global forces than fifty years ago. This is true with a diversity of recent examples, including struggles with the Environmental Protection Agency to make sure tribal waters are afforded the same protections as Euro-American communities, protecting cultural heritage on and off reservations, or dealing with disproportionate harm resulting from climate change $[5,6,75,76]$.

Acknowledgments: I would like to thank the White Mountain Apache Tribe, John Welch, Jonathan Long, and Mark Barrow for their help with this project. The special issue editors and three anonymous reviewers also greatly improved this article.

Conflicts of Interest: The author declares no conflict of interest.

\section{References and Notes}

1. Arturo Escobar. "Culture Sits in Places: Reflections on Globalization and Subaltern Strategies of Localization." Political Geography 20 (2001): 139-74. [CrossRef]

2. Arturo Escobar. Territories of Difference. Durham: Duke University Press, 2008.

3. Richard White. The Middle Ground: Indians, Empires, and Republics in the Great Lakes Region, 1650-1815. Cambridge: Cambridge University Press, 1991.

4. James Merrell. The Indians New World: Catawbas and their Neighbors from European Contact through the Era of Removal. New York: W.W. Norton \& Company, 1991.

5. Charles Wilkinson. Blood Struggle: The Rise of Modern Indian Nations. New York: W. W. Norton \& Company, 2005.

6. Clint Carrol. Roots of Our Renewal: Ethnobotany and Cherokee Environmental Governance. Minneapolis: University of Minnesota Press, 2015. 
7. John Welch. "The White Mountain Apache Tribe Heritage Program: Origins, Operations, and Challenges." In Working Together: Native Americans and Archaeologists. Edited by Kurt Dongoske, Mark Aldenderfer and Karen Doehner. Washington: Society for American Archaeology, 2000, pp. 67-83.

8. David Turnbull. Masons, Tricksters and Cartographers. New York: Routledge, 2000.

9. Ron Eglash. "Appropriating Technology: An Introduction." In Appropriating Technology: Vernacular Science and Social Power. Edited by Ron Eglash and Jennifer Croissant. Minneapolis: University of Minnesota Press, 2004, pp. vii-xx.

10. Sandra Harding. Is Science Multicultural? Bloomington: Indiana University Press, 1998.

11. Robert Cantwell. “The Happiest Fishing Ground." Sports Illustrated 31 (1969): 37-42.

12. David Tomblin. "White Mountain Apache Boundary-work as an Instrument of Ecopolitical Liberation and Landscape Change." In New Natures: Joining Environmental History with Science and Technology Studies. Edited by Dolly Jorgensen, Finn Arne Jorgensen and Sara Pritchard. Pittsburgh: University of Pittsburgh Press, 2013, pp. 179-94.

13. Vine Deloria, Jr. Custer Died for Your Sins. Norman: University of Oklahoma Press, 1970.

14. Mark Spence. Dispossessing the Wilderness. Oxford: Oxford University Press, 1999.

15. Donald Pisani. "Irrigation, Water Rights, and the Betrayal of Indian Allotment." In Out of the Woods. Edited by Char Miller and Hal Rothman. Pittsburgh: University of Pittsburgh Press, 1997, pp. 243-60.

16. Karl Jacoby. Crimes Against Nature. Berkeley: University of California Press, 2001.

17. Keith Basso. "Western Apache." In Handbook of North American Indians, Volume 10: Southwest. Edited by Alfonso Ortiz. Washington: Smithsonian, 1983, pp. 462-88.

18. Richard Perry. Western Apache Heritage. Austin: University of Texas Press, 1991.

19. U.S. Census Bureau, 2010. Available online: http://www.census.gov/2010census/ (accessed on 3 February 2016).

20. White Mountain Apache Tribe Website. Available online: http://www.wmat.nsn.us/ (accessed on 24 November 2015).

21. Resolution of the White Mountain Apache Tribe, No. 53-50, Record Group 75, Fort Apache Indian Reservation (hereafter RG75 FAIR), United States National Archives.

22. Richard White. Roots of Dependency. Lincoln: University of Nebraska Press, 1983.

23. Clayton Koppes. "From New Deal to Termination: Liberalism and Indian policy, 1933-1953." Pacific Historical Review 46 (1977): 543-66. [CrossRef]

24. Kenneth Philp. Termination Revisited. Lincoln: University of Nebraska Press, 1999.

25. Donald Fixico. Termination and Relocation. Albuquerque: University of New Mexico Press, 1986.

26. U.S. House of Representatives Concurrent Resolution 108, 67 Stat. B132 (1953).

27. Donald Parman. Indians and the American West in the Twentieth Century. Bloomington: University of Indiana Press, 1994.

28. Crow to Miller, 18 June 1953, RG75 FAIR, United States National Archives.

29. Peter Iverson. "Building toward Self-Determination." The Western Historical Quarterly 16 (1985): 163-73. [CrossRef]

30. Nelson Lupe interview with Eugene Fugle, 1962, transcribed by Charles Kaut, transcript on file with author.

31. John Welch. "'A Monument to Native Civilization': Byron Cummings Still-Unfolding Vision for Kinishba Ruins." Journal of the Southwest 49 (2007): 1-94. [CrossRef]

32. Weaver to Zeh, 1 June 1948, Memorandum: Forestry Situation on the Fort Apache Indian Reservation, RG75 FAIR, United States National Archives.

33. L. D. Arnold. Proposed Meritorious Honor Award for Mr. Silas O. Davis, 7 March 1952, Forest History Society Archives, Harold Weaver Papers, Durham, North Carolina.

34. Harry Kallander to Harold Weaver, 28 July 1952, Forest History Society Archives, Harold Weaver Papers, Durham, North Carolina.

35. Resolution of the WMAT, No. 53-22, 4 June 1953, RG75 FAIR, United States National Archives.

36. Plan of Operations for the White Mountain Recreational Enterprise, RG75 FAIR, United States National Archives.

37. Anonymous. "Hawley Given Int. Dept. Highest Service Award." Fort Apache Scout, April 1966, p. 8.

38. Haverland to Commissioner, 15 May 1958, RG75 FAIR, United States National Archives.

39. Jo Baeza. "Former Chairman to be Marshall." Fort Apache Scout 27 (1988): 17. 
40. Haverland Memorandum for the Records, 13 December 1955, RG75 FAIR, United States National Archives.

41. Massey to White Mountain Apache Tribal Council, 7 March 1957, RG75 FAIR, United States National Archives.

42. Kessay to Emmons, 8 January 1957, RG75 FAIR, United States National Archives.

43. Fritz to Haverland, 18 October 1956, RG75 FAIR, United States National Archives.

44. Thomas Cowger. “'The Crossroads of Destiny': The NCAI's Landmark Struggle to Thwart Coercive Termination." American Indian Culture and Research Journal 20 (1996): 121-44. [CrossRef]

45. Massey to Haverland, 28 March 1957, RG75 FAIR, United States National Archives.

46. White Mountain Apache Tribal Council Resolution No. 57-31, April 15, 1957, RG75 FAIR, United States National Archives.

47. Anonymous. "Yesterday's Leaders are Today's Elders." Fort Apache Scout, 13 April 1979, 18.

48. Jack Hemphill. “Fishery Management Report: Smith Park Lake.” 15 November 1956, RG75 FAIR, United States National Archives.

49. Haverland to Commissioner, 15 August 1960, RG75 FAIR, United States National Archives.

50. Ben Avery. “Indian Water Rights Big Issue." The Arizona Republic, 16 June 1957, pp. 1-2.

51. Thomas Lesture. "Riding the Trails in Apache Territory." New York Times, 5 June 1960, p. XX46.

52. Charles Hebert. "Land of the White Mountain Apaches." Arizona Highways 37 (1962): 1-43.

53. Robert Hyatt. "Apacheland Welcomes White Man." American Legion Magazine, March 1962, pp. 14-15, 38-39. RG75 FAIR, United States National Archives.

54. Roderick Nash. Wilderness and the American Mind. New Haven: Yale University Press, 2001.

55. Samuel Hays. Beauty, Health, and Permanence. Cambridge: Cambridge University Press, 1987.

56. Richard Dunlop. “Apache Camp-Out." Saturday Evening Post, 11 August 1962, p. 75.

57. Oliver to Kephart, 17 April 1959, RG75 FAIR, United States National Archives.

58. White Mountain Apache Tribal Resolution 54-15, RG75 FAIR, United States National Archives.

59. Memorandum of Agreement between the Arizona Game and Fish Commission, The White Mountain Apache Tribe, and the Fish and Wildlife Service for the Operation of the Williams Creek (McNary) Fish Hatchery, 27 May 1954, RG75 FAIR, United States National Archives.

60. Joe Huston. Trout Shocking Study, Fort Apache Indian Reservation, Arizona, RG75 FAIR, United States National Archives.

61. Anonymous. “To Greener Pastures: Fleet Antelope Trapped for White Mountain Transplant." The Arizona Republic, 1 October 1959, p. 16.

62. Anonymous. "Antelope Herd Increase Noted." Fort Apache Scout, August 1962, p. 1.

63. Jack Hemphill. Fishery Management Report, 11 December 1957, RG75 FAIR, United States National Archives.

64. White Mountain Apache Tribal Council Minutes, 7 February 1962, RG75 FAIR, United States National Archives.

65. Dean Nieusma. “Middle-out Social Change: Expert-ed Development Interventions in Sri Lanka's Energy Sector." In Technoscience and Environmental Justice. Edited by Gwen Ottinger and Benjamin Cohen. Cambridge: MIT Press, 2011, pp. 119-45.

66. John Welch, Dana Lepofsky, Megan Caldwell, Georgia Combes, and Craig Rust. "Treasure Bearers: Personal Foundations for Effective Leadership in Northern Coast Salish Heritage Stewardship." Heritage and Society 4 (2011): 83-114. [CrossRef]

67. Veronica Tiller, and Arthur Gómez. Fort Apache Forestry: A History of Timber Management and Forest Protection on the Fort Apache Indian Reservation, 1870-1985. Washington: Bureau of Indian Affairs, 1990.

68. Thomas McGuire. Mixed Bloods, Apaches, and Cattle Barons: Documents for a History of the Livestock Economy on the White Mountain Reservation, Arizona (Archeological Series No. 142). Tucson: Arizona State Museum, 1980.

69. David Getches, Charles Wilkinson, and Robert Williams, Jr. Cases and Materials on Federal Indian Law. St. Paul: West Group, 1998.

70. Marren Sanders. Implementing the Federal Endangered Species Act in Indian Country. Tucson: Joint Occasional Papers on Native Affairs, 2007.

71. John Welch. "Reconstructing an Ndee Sense of Place." In The Archaeology of Meaningful Places. Edited by Brenda J. Bowser and María Nieves Zedeño. Salt Lake City: The University of Utah Press, 2009, pp. 149-62. 
72. Jonathan Long, Aregai Tecle, and Benrita Burnette. “Cultural Foundations for Ecological Restoration on the White Mountain Apache Reservation." Conservation Ecology 8 (2003): 4. Available online: http: //www.consecol.org/vol8/iss1/art4 (accessed on 3 February 2016).

73. Gail Pechuli. "White Mountain Apache tribe uses BAER to restore charred land." Indian Country Today, 3 February 2003.

74. John Welch. "The Rodeo-Chediski Fire and Cultural Resources.” Arizona Archaeological Council Newsletter 26 (2002): 1-3.

75. Jaclyn Johnson, and Darren Ranco. "Risk Assessment and Native Americans at the Cultural Crossroads." In Technoscience and Environmental Justice. Edited by Gwen Ottinger and Benjamin Cohen. Cambridge: MIT Press, 2011, pp. 179-200.

76. Kyle Whyte. "Justice Forward: Tribes, Climate Adaptation and Responsibility." Climate Change 120 (2013): 517-30. [CrossRef]

(C) 2016 by the author; licensee MDPI, Basel, Switzerland. This article is an open access article distributed under the terms and conditions of the Creative Commons Attribution (CC-BY) license (http://creativecommons.org/licenses/by/4.0/). 